\title{
Deskripsi Daging Rana Arfaki (Anura; Ranidae) yang Dikonsumsi Masyarakat Moiley di Pegunungan Arfak
}

\section{Description of Rana Arfaki (Anura; Ranidae) Meat Consumed by Moiley Communities at the Arfak Mountain}

\author{
Anita Oce Athabu' ${ }^{1}$, Daniel Y. Seseray ${ }^{1}$, Freddy Pattiselanno $\left.{ }^{2,3}\right)^{*}$ \\ ${ }^{1)}$ Program Studi Peternakan, Fakultas Peternakan, UNIPA, Manokwari, 98314, Indonesia \\ ${ }^{2)}$ Program Studi Budidaya Ternak, Fakultas Peternakan, UNIPA, Manokwari, 98314, Indonesia \\ ${ }^{3)}$ Pusat Penelitian Keanekaragaman Hayati, UNIPA, Manokwari 98314, Indonesia
}

Article history

Received: Jun 22, 2020;

Accepted: Aug 18, 2021

* Corresponding author:

E-mail:

f.pattiselanno@unipa.ac.id

DOI:

10.46549/jipvet.v11i3.199

\section{(c) (1) (2) (2) D) OPENA Access}

\begin{abstract}
In Papua, especially in the Arfak Mountains, one of wild animals that commonly used as a non-animal protein source is frogs. Although it has been consumed by local people for generations, there is no representative information on the characteristics of Arfak frog meat. This study aims to determine the body weight and weight of carcass of Arfak frogs (Rana arfaki) comsumed by the Moiley communtiies in the Arfak Mountains. In addition, this study also attempts to reveal the physical quality and processing techniques of consumed Arfak forg meat. We used descriptive method with observation techniques in the field. The results show that an average body weight of Arfak frogs consumed in Mbenti is $2.53 \pm 0.81 \mathrm{gr}$, with an average of carcass percentage $46.77 \%$ and non-carcass percentage $53.23 \%$. The physical quality of the meat is, fresh and looks intact, the color of flesh and muscles is white to yellowish white, has a distinctive aroma, and elastic texture as well as strong muscles. The $\mathrm{pH}$ value of fresh meat is an average of 7.03. Various meat processing techniques are practiced including fried, stir-fry, grilled and smoked, and pickling/smoked is more preffered bacuse it is easy and the meat can keep longer as a source of food for household animal protein.
\end{abstract}

Keywords: Arfak; Cosnsumption; Meat; Quality; Rana arfaki

\section{Abstrak}

Di Papua khususnya di Pegunungan Arfak, salah satu jenis satwa yang dimanfaatkan masyarakat sebagai sumber protein hewani non-ternak adalah katak. Meskipun telah dikonsumsi oleh masyarakat lokal secara turun temurun, sampai saat ini belum tersedia informasi yang representatif tentang karakteristik daging katak Arfak. Tujuan dari penelitian ini adalah untuk mengetahui bobot badan dan berat karkas katak Arfak (Rana arfaki) yang dikonsumsi masyarakar Moiley di Pegunungan Arfak. Selain itu juga penelitian ini bertujuan untuk mengetahui kualitas fisik dan teknik pengolahan daging katak Arfak yang dikonsumsi. Metode yang digunakan adalah metode deskriptif dengan teknik observasi atau pengamatan langsung di lapangan. Rataan bobot badan katak Arfak (Rana arfaki) yang dikonsumsi oleh masyarakat di Mbenti yaitu 2,53 $\pm 0,81 \mathrm{gr}$ dengan rataan persentase karkas yaitu 46,77\% dan persentase non-karkasnya sebesar 53,23\%. Kualitas fisik daging katak Arfak yaitu memiliki karakteristik segar dan tampak utuh, warna daging dan otot putih hingga putih kekuningan, memiliki aroma khas, dengan tekstur elastis serta memiliki otot kuat. Sedangkan nilai $\mathrm{pH}$ daging katak Arfak segar yang dikonsumsi oleh masyarakat yaitu rata-rata adalah 7,03. Teknik pengolahan daging yang dilakukan oleh masyarakat beragam antara lain goreng, tumis, bakar dan asap. Cara asar/asap lebih disenangi karena mudah dilakukan dan 
dapat memperpanjang masa simpan daging sebagai cadangan sumber pangan protein hewani rumah tangga.

Kata kunci: Arfak; Daging; Konsumsi; Kualitas; Rana arfaki

\section{PENDAHULUAN}

Di Papua, konsumsi protein hewani masyarakat belum memenuhi standar yang ditetapkan Food and Agriculture Organisation (FAO), dan konsumsi daging pada tahun 2017 mencapai 4,20 gram/kapita/hari, meningkat sebesar 25,37 persen dibandingkan konsumsi tahun 2016 sebesar 3,35 gram, (Dirjennakkeswan, 2018). Oleh karena itu masyarakat memanfaatkan protein hewani nonternak untuk memenuhi kebutuhan gizi keluarga (Pattiselanno, 2006). Di sisi lain, faktor pembatas kondisi geografis menyebabkan sumber protein hewani asal ternak tidak terdistribusi dengan merata. Kalaupun bisa terdistribusi, harganya sudah meningkat dan menjadi mahal. Sementara itu, sumber protein hewani non-ternak seperti satwa liar sangat melimpah di Papua, merupakan sumber protein hewani akternatif yang lain sering dimanfaatkan oleh masyarakat (Pattiselanno, 2003; Pattiselanno, 2006).

Satwa liar banyak dimanfaatkan oleh masyarakat sebagai sumber protein hewani non-ternak di Papua, dan ditemukan melimpah di habitat yang beragam dalam kawasan hutan di Papua. Di Papua khususnya di Pegunungan Arfak, salah satu jenis satwa yang dimanfaatkan masyarakat sebagai sumber protein hewani non-ternak adalah katak. Hasil penelitian (Ullo 2014), telah mengungkap kandungan gizi katak Arfak (Rana arfaki). Namun demikian, informasi spesifik tentang karakteristik daging katak Arfak ini khususnya belum tersedia. Penduduk lokal di Minyambou, wilayah Cagar Alam Pegunungan merupakan salah satu daerah yang mengkonsumsi katak Arfak sebagai salah satu pangan penyumbang protein hewani non-ternak secara turuntemurun. Hal yang sama juga dilakukan oleh masyarakat di Manggarai Timur yang mengkonsumsi katak sawah (Rana cancrivora) sebagai sumber protein hewani keluarga karena kandungan gizinya yang tinggi (Antus et al., 2018).
Meskipun telah dikonsumsi oleh masyarakat lokal secara turun temurun, sampai saat ini belum tersedia informasi yang representatif tentang karakteristik daging katak Arfak, khususnya bobot badan yang dimanfaatkan oleh masyarakat. Hal ini cukup beralasan, karena pemanenan yang tidak memperhatikan bobot badan katak akan berdampak terhadap populasi dengan bobot badan tertentu atau populasi katak produktif di alam. Untuk tujuan pemanfaatan yang tidak terkendali yang dikuatirkan berdampak terhadap kondisi populasi katak di alam, informasi tentang bobot badan dan bobot karas katak Arfaki perlu diketahui. Tersedianya informasi bobot badan, berat karkas dan teknik pengolahan katak Arfak akan menjadi informasi dasar untuk pemanfaatan berkelanjutan sekaligus menunjang program konservasi katak Arfak di alam.

Tujuan dari penelitian ini adalah untuk mengetahui bobot badan dan berat karkas katak Arfak (Rana arfaki) yang dikonsumsi masyarakar Moiley di Pegunungan Arfak. Selain itu juga penelitian ini bertujuan untuk mengetahui kualitas fisik dan teknik pengolahan daging katak Arfak yang dikonsumsi.

\section{MATERI DAN METODE}

\section{Metode Penelitian}

Penelitian ini dilaksanakan di Kampung Mbenti Distrik Minyambouw di Pegunungan Arfak dan Sub lab Teknologi Hasil Ternak Fakultas Peternakan Universitas Papua. Penelitian ini dilakukan dari bulan Juni hingga bulan September, tahun 2017.

\section{ALAT DAN BAHAN}

Materi yang digunakan dalam penelitian ini adalah katak Arfak (Rana arfaki). Sedangkan alat yang digunakan dalam penelitian ini adalah kamera digital, timbangan analitik, kaliper, senter, minyak tanah, alat tulis menulis, $\mathrm{pH}$ meter dan plastik polietilen. 


\section{CARA KERJA}

Metode yang digunakan adalah metode deskriptif dengan teknik observasi atau pengamatan langsung di lapangan. Katak hasil tangkapan masyarakat untuk dikonsumsi, dikumpulkan dan disortir menurut kisaran bobot badannya. Setelah proses penyortiran selesai, katak ditimbang untuk mengetahui bobot hidupnya.

Selanjutnya katak yang diproses untuk dikonsumsi dikeluarkan isi perutnya. Setelah itu dilakukan penimbangan karkas untuk memperoleh total karkas secara keseluruhan dari daging katak tersebut. Setelah itu dilakukan uji fisik dari katak untuk melihat warna dan $\mathrm{pH}$ daging. Selanjutnya dilakukan pengamatan proses pengolahan daging katak Arfak yang umumnya dilakukan masyarakat seeprti (rebus, tumis, goreng, asar, bungkus dengan kulit kayu, kukus) untuk melihat teknik ataupun cara mengolah katak yang dilakukan oleh masyarakat itu sendiri.

\section{ANALISIS DATA}

Data yang di kumpulkan dianalisis secara deskriptif, dan disajikan dalam bentuk tabel dan gambar.

\section{HASIL DAN PEMBAHASAN}

Sebagai salah satu sumber protein hewani alternatif masyarakat Suku Moiley di Kampung Mbenti, katak Arfak diperoleh dengan cara berburu dan telah dilakukan secara turuntemurun. Alat bantu yang biasa digunakan adalah kantung plastik, senter, obor, karung dan parang. Kegiatan penangkapan biasanya lebih intens dilakukan pada musim-musim tertentu seperti pada saat bulan gelap, karena diyakini hasil tangkapan akan lebih banyak. Jenis katak yang dikonsumsi oleh kelompok etnik Moiley di Kampung Mbenti berdasarkan pengamatan yang dilakukan disajikan pada Gambar 1 .

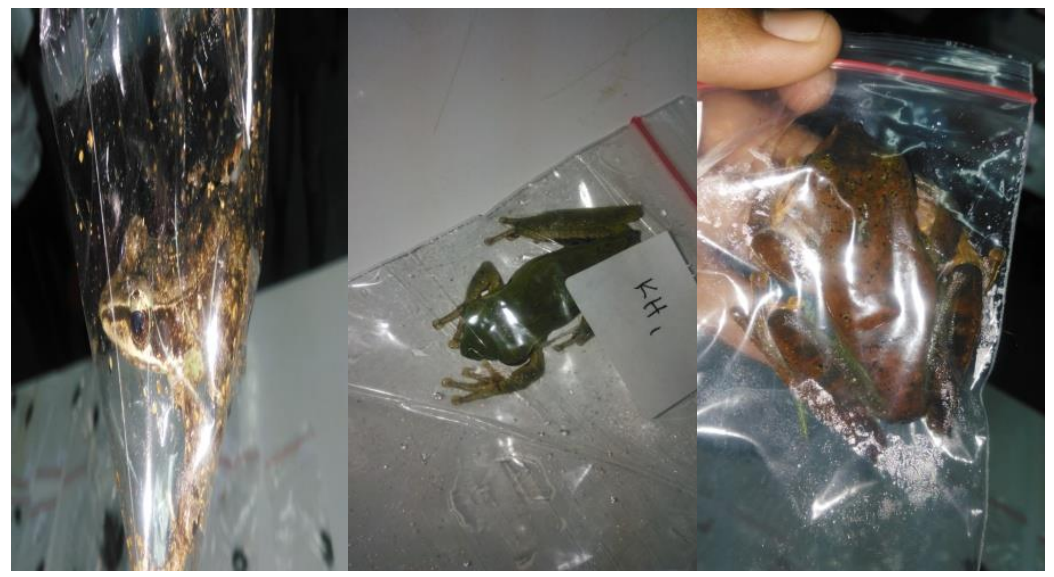

Gambar 1. Sampel katak Arfak (Rana arfaki) yang diteliti

\section{BOBOT BADAN, BOBOT KARKAS DAN NON KARKAS}

Hasil pengukuran terhadap bobot badan, bobot karkas dan bobot non-karkas sampel katak Arfak hasil buruan masyarakat disajikan dalam Tabel 1.

Ternyata bahwa bobot badan katak yang dikonsumsi bervariasi antara 1,60 hingga 5,50 gram dengan rata-rata bobot badan adalah 2,53 gram. Hasil ini agak berbeda dengan bobot badan katak Arfak yang yang diteliti Ullo (2014) dengan rata-rata bobot badan 5,4 gram.
Perbedaan bobot badan ini disebabkan karena $R$. arfaki kemungkinan mengandung variasi geografis yang tinggi (Donnelan et al., 2010), dan hal ini ikut mempengaruhi ukuran morfomteri tubuhnya. Selain itu juga, perbedaan bobot badan katak Arfak kemungkinan disebabkan karena perbedaan factor genetic, ketersediaan bahan pakan dan kondisi lingkungan tempat hidup dan umur hewan (Williamson and Payne, 1993).

Hasil penelitian Widiatmoko (1999) di lima daerah sepanjang aliran sungai di Pegunungan Arfak sangat berbeda dengan hasil 


\section{Athabu et al.,}

dalam penelitian ini. Kisaran bobot badan katak betina adalah 93,53 \pm 19,65gr (betina) dan 72,23 $\pm 1,77$ (jantan) (Widiatmoko, 1999). Katak Arfak (Rana arfaki) memiliki enam subspecies yang berbeda (Menzies, 1976), oleh karena itu, kemungkinan perbedaan bobot badan ini diduga karena sub-species yang diamati juga berbeda. Review terakhir sistematik katak Rana yang dilakukan oleh Menzies (1987) mendokumentasikan sepuluh spesies yang menyebar di pulau utama New Guinea, empat spesies lainnya menyebar di pulau-pulau satelit di timur dan barat. Oleh karena itu penamaan spesies ini juga telah mengalami beberepa kali revisi secara sistematik dan penamaan yang terakhir spesies ini adalah Papurana arfaki (Oliver et al., 2015), atau katak Arfak (Frank and Ramus, 1995) atau katak sungai besar (Menzies, 1976).

Tabel 1. Rata-rata bobot badan (Gram), bobot karkas dan non karkas (Gram), Persentasi Karkas dan Non Karkas Katak.

\begin{tabular}{lccccc}
\hline \multirow{2}{*}{ Uraian $(\mathrm{N}=30)$} & \multicolumn{3}{c}{ Bobot $(\mathrm{Gram})$} & \multicolumn{2}{c}{ Persentasi $(\%)$} \\
\cline { 2 - 6 } & Badan & Karkas & Non Karkas & Karkas & Non Karkas \\
\hline Maksimal & 5,50 & 1,90 & 3,60 & 64,71 & 66,67 \\
Minimal & 1,60 & 0,80 & 0,60 & 33,33 & 35,29 \\
\hline Rata-rata & $2,53 \pm 0,81$ & $1,15 \pm 0,23$ & $1,39 \pm 0,63$ & $46,77 \pm 7,32$ & $53,23 \pm 7,32$ \\
\hline
\end{tabular}

Ternyata bahwa untuk tujuan konsumsi, tidak ada batasan bobot badan katak tertentu, sehingga variasi bobot badan hasil buruan cukup tinggi. Hasil buruan yang diperoleh secara aksidental, tanpa memperhatikan bobot badan dikuatirkan mempengaruhi keberadaan populasi karak Arfak di alam. Hal ini juga kurang baik bagi keberlanjutan kehidupan katak Arfak di alam, jika terus menerus berlangsung. Dikuatirkan katak ini telah terlebih dahulu diburu/dan ditangkap sebelum bereproduksi, sehingga mempengaruhi populasinya di alam.

Hasil wawancara terhadap kelompok masyarakat suku Moiley di kampung Mbenti menunjukan bahwa dalam proses pengolahan daging katak Arfak, tidak ada bagian tubuh katak yang dibuang. Artinya bahwa $100 \%$, atau semua bagian tubuh katak Arfak dikonsumsi dan tidak ada bagian tubuh yang dibuang. Menurut pengakuan masyarakat, daging dan kulit katak diyakini berhasiat sebagai obat penyakit gatal-gatal dan menjadi tradisi turun temurun dalam mengonsumsi katak.

Bobot karkas dihitung berdasarkan pada SNI 01-2706.3-2006 yang mengatur tentang produk paha katak yang higienis, dan aman untuk dikonsumsi. Kriteria SNI ini menitik beratkan pada persyaratan bahan baku mulai dari jenis, bentuk, asal hingga mutu dan cara penyimpanan. Bahan baku harus katak utuh hidup yang belum mengalami pengolahan dan berasal dari alam atau budidaya yang tidak tercemar. Karkas katak adalah bagian tubuh katak yang sudah di pisahkan dari kulit, kaki, kepala dan isi perut. Hasil perhitungan rata-rata bobot karkas katak Arfak adalah 1,15 gram atau dengan rata-rata persentasi $46,77 \%$. Rataan bobot non-karkas adalah 1,39 gram dengan rata-rata persentasinya adalah $53,23 \%$.

\section{KUALITAS FISIK DAN TEKNIK PENGOLAHAN DAGING RANA ARFAKI}

Kualitas fisik daging katak Arfak yang diamati memiliki karakteristik segar dan tampak utuh, warna daging dan otot putih hingga putih kekuningan, elastis dan otot kuat. Sedangkan nilai $\mathrm{pH}$ dari daging katak Arfak segar yang dikonsumsi oleh masyarakat di Cagar Alam Pegunungan Arfak (CAPA) ratarata adalah 7,03 dengan perolehan $\mathrm{pH}$ maksimal adalah 7,20. Dan $\mathrm{pH}$ minimumnya adalah 6,08. Hasil ini memberikan indikasi bahwa daging katak Arfak berada pada $\mathrm{pH}$ normal. Nilai $\mathrm{pH}$ ini juga memberikan gambaran bahwa kondisi daging masih berada pada fase pre-rigor (Lawrie, 2003).

Teknik pengolahan daging katak Arfak untuk dikonsumsi oleh masyarakat suku Moiley di Kampung Mbenti dikenal beragam antara lain dengan cara dipanggang/bakar di atas bara api, diasar atau asap, goreng dan tumis (Gambar 2). 


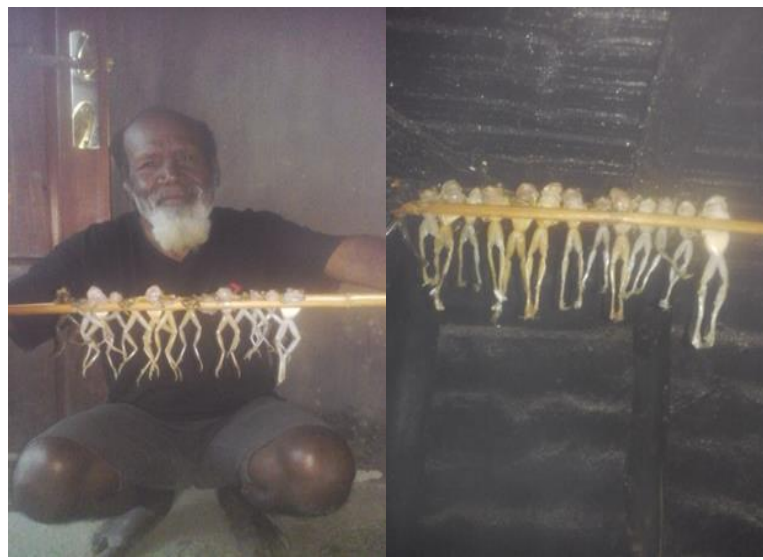

Gambar 2. Proses pengolahan daging katak Arfak (Rana arfaki)

Berdasarkan hasil pengamatan yang dilakukan, masyarakat menangkap katak secara langsung menggunakan tangan dan meletakannya didalam kantung plastic atau karung yang disediakan kemudian dibiarkan sampai katak tersebut mati lemas. Jika kataknya masih hidup, maka masyarakat membuat katak tersebut mati. Setelah itu katak dicuci dan dibilas dengan air bersih sebelum diolah.

Pengolahan daging katak dilakukan tanpa mengeluarkan organ dalam, kulit dan kepala. Masyarakat mengolah katak secara langsung dengan cara dibilas dengan air dan di bakar di atas bara api atau dijepit dengan bambu (Gambar 2), untuk diasar/asap. Katak yang diproses dengan cara pengasapan ini dagingnya dapat disimpan dalam jangka waktu yang lama, kemudian dihancurkan dan dicampurkan dengan sayur-sayuran pada saat dimasak. Hal ini sesuai dengan penelitian Ullo (2014), menyatakan bahwa cara mengolah daging katak yaitu membakar di tungku api, mengasar daging katak sampai kering dan digoreng. Lebih lanjut dikatakan bahwa katak yang di asar dapat bertahan lebih lama dan dapat dimasak sebagai campuran sayur-sayuran.

Hasil wawancara menunjukkan bahwa $100 \%(\mathrm{n}=30)$ masyarakat menggunakan ke empat teknik pengolahan tersebut. Namun mengolah dengan cara pengasapan lebih disukai masyarakat karena selain lebih awet, daging memiliki masa simpan yang lebih lama serta cara pengolahan daging yang praktis dan mudah dilakukan sebagai cadangan sumber protein hewani rumah tangga.

\section{KESIMPULAN}

Rataan bobot badan katak Arfak (Rana arfaki) yang dikonsumsi oleh masyarakat di Mbenti yaitu 2,53gr dengan rataan persentase karkas yaitu $46,77 \%$ dan persentase nonkarkasnya sebesar 53,23\%. Kualitas fisik daging katak Arfak yaitu memiliki karakteristik segar dan tampak utuh, warna daging dan otot putih hingga putih kekuningan, memiliki aroma khas, dengan tekstur elastis serta memiliki otot kuat. Sedangkan nilai $\mathrm{pH}$ yang diperoleh dari daging katak Arfak segar yang dikonsumsi oleh masyarakat yaitu rata-rata adalah 7,03. Dikenal beberapa teknik pengolahan daging yang dilakukan oleh masyarakat antara lain goreng, tumis, bakar dan asap. Teknik pengolahan dengan cara asar/asap lebih disenangi karena mudah dilakukan dan dapat memperpanjang masa simpan daging sebagai cadangan sumber pangan protein hewani rumah tangga.

\section{UCAPAN TERIMA KASIH}

Kepada aparat pemerintahan dan para responden di Kampung Mbenti, terima kasih karena sudah mengijinkan pengambilan data selama penelitian berlangsung dan ikut berpartisipasi dalam kegiatan penelitian ini.

\section{DAFTAR PUSTAKA}

Antus, M.R., Dima, A.O.M., Meye, E.D. 2018. Ecological analysis, orphology and nutritional value of Rana cancrivora in East Manggarai. Jurnal Biotropikal Sains 15(2): 38-44

Donnelan, S.C., Aplin, K.P., Bertozzi, T. 2010. Species boundaries in the Rana arfaki 
group (Anura: Ranidae) and phylogenetic relationships to other New Guinean Rana. Zootaxa 2496: 49-62

Frank, N., and Ramus, E. 1995. Complete Guide to Scientific and Common Names of Amphibians and Reptiles of the World. Pottsville, Pennsylvania: N. G. Publishing Inc.

Lawrie, R. A. 1995. Meat Science 5th Edition. Pergamon Press, New York.

Menzies, J. I. (1987). "A taxonomic revision of Papuan Rana (Amphibia, Ranidae)". Australian Journal of Zoology 35 (4): 373-418.

Menzies, J. I. 1976. Handbook of Common New Guinea Frogs. Wau Ecology Institute Handbook 1. Hong Kong: Sheck Wa Tong.

Oliver, L., Prendini, E., Kraus, F., Raxworthy, C.J. 2015. Systematics and biogeography of the Hylarana frog (Anura: Ranidae) radiation across tropical Australasia, Southeast Asia, and Africa.
Molecular Phylogenetics and Evolution 90: 176-192.

Pattiselanno, F. 2003. The wildlife value: Example from West Papua, Indonesia. Tigerpaper 30 (1): 27-29

Pattiselanno, F. 2006. The wildlife hunting in Papua. Biota 11(1): 59-61

Ullo .2014.Ukuran Morfometrik dan Kandungan Gizi dari beberapa jenis Katak yang di Konsumsi. [Skripsi] Sarjana Fakultas Peternakan Universitas Papua. Manokwari

Widiatmoko, A. 1999. Karakteristik Morfologis dan Habitat Katak Arfak Dewasa (Rana Arfaki Meyer; Ranidae; Amphibia) di Beberapa Aliran Sungai pada Kawasan Pegunungan Arfak Kabupaten Daerah Tingkat II Manokwari. [Skripsi] Jurusan Kehutanan Fakultas Pertanian Universitas Cenderwasih, Manokwari.

Williamson, G. dan Payne, W.J.A. 1993. Pengantar Peternakan di Daerah Tropis. Alih Bahasa: Djiwa Darmadja. UGM Press. Yogyakarta. 